substantial convention could be kept open almost until the last minute, by keeping controversial sections 'bracketed off' from the main text, to be included if there is a change of heart by the United States. He believes that some measures, including clauses on deforestation, strengthening climate monitoring and defining financial arrangements to help poorer countries to develop their economies while minimizing greenhouse gas emissions, may well be included.

The inclusion of carbon dioxide emission targets (themselves an interim step towards integrated controls encompassing all greenhouse gases) is far less likely. But the United States may find itself forced into conceding some targets if many nations produce their own emissions strategies before 1992. The positions of individual countries will become clearer during the two-day ministerial meeting which concludes the World Climate Conference in Geneva in November. The urgency with which the international community wishes to address climate change convention negotiations should also be evident in the meeting's final declaration.
European Communities (EC) partners failed to reach a common position on carbon dioxide emissions when ministers last debated the issue in June. Spain, showing little interest in the problem, is the main stumbling block. But another meeting is planned for 29 October, and it is possible that a general EC target can be set, within which Spain and the other southern European nations have some leeway. The slack could be made up by EC member states already committed to stronger action, such as the Netherlands and West Germany.

A firm emissions target from Japan will be influential, since the Japanese have been seen as part of the camp opposed to emissions targets which is headed by the United States and backed by the Soviet Union and Saudi Arabia. Japan has reasonably complained that, as the most energy-efficient nation in the developed world, it has already done more than most to address the emissions problem (see table). But Japan is expected to announce during October a plan to stabilize its emissions by 2000 , albeit at a level marginally higher than today.

Peter Aldhous

\title{
Stripped for action
}

\section{Paris}

After two years of discussions, the special committee of the International Geosphere-Biosphere Programme (IGBP) on global change met last week in Paris to discuss details of a set of five honed-down 'core projects' which it expects governments to back over the next 10 to 20 years. Although data from these first projects are seen as essential if politicians are to make informed decisions on global change issues, IGBP officials are still concerned that not all governments are fully committed to the programme. A special problem will be the need to gather information from parts of the globe occupied by underdeveloped nations that lack their own research capabilites.

IGBP was put together by the International Council of Scientific Unions (ICSU) in September 1986 and, with the World Climate Research Programme (jointly sponsored by ICSU and the World Meteorological Organisation), is the coordinating power behind the international effort to understand global change. United Nations backing came with a General Assembly resolution passed in December 1989.

The Paris meeting exuded an air of selfcongratulation, as though a difficult job had been well done. According to MarieLouise Chanin, one of the 19 members of the IGBP special committee, any project not judged immediately relevant to a list of seven critical questions on global change was eliminated over the course of meetings involving more than 500 scientists. The five surviving projects will look at global atmospheric chemistry, global ocean flux, biospheric aspects of the hydrological cycle, terrestrial ecosystems and global changes over the past 2,000 years. Several of these projects have already started.

IGBP now has 46 member nations but, says French Research Minister Hubert Curien, "there are some serious gaps, particularly in South America, Africa and Oceania". The problem for poorer countries, says Dr E. Diop of Senegal, is that they tend to be submerged by immediate problems such as drought and famine, and do not look for long-term causes and effects. IGBP now hopes to overcome this isolation by creating a series of regional research centres in developing countries. These will concentrate attention on synthesis and modelling projects particularly relevant to regional priorities, while providing opportunities for training and exchange.

Now that the planning phase is complete, said John Wood, of the marine sciences directorate at the UK Natural Environment Research Council (NERC), IGBP must be implemented. Core projects will be funded through national research agencies, with coordination ensured by 'core project offices' dotted around the world. So far, offices have been set up in Kiel and Berlin (Germany), Berne (Switzerland) and Paris. The Paris office, to be located at the University of
Room for improvement on emissions

THE table shows 1987 greenhouse gas emissions for a number of key countries, compiled by the World Resources Institute (WRI). Emissions of methane and chlorofluorocarbons have been converted to quantities of carbon dioxide with the same heating effect, and the figures include the effect

GREENHOUSE GAS EMISSIONS (TONNES OF CARBON EQUIVALENT)

\begin{tabular}{lcc}
\hline & Total (millions) & Per capita \\
US & 1.00 & 4.1 \\
Soviet Union & 0.77 & 2.7 \\
European Communities & 0.76 & 2.3 \\
Brazil & 0.47 & 3.3 \\
China & 0.44 & 0.4 \\
Japan & 0.23 & 1.9 \\
W. Germany & 0.17 & 2.8 \\
UK & 0.15 & 2.6 \\
\hline
\end{tabular}

of deforestation on the carbon dioxide budget. The total emissions figures identify the main 'climate polluters', says Allen Hammond from WRI. He believes the ultimate aim of an international agreement should be to reduce emissions from these countries. When Germany is reunified, European Communities emissions will exceed those of the Soviet Union. But any agreement must also take account of the varying extent to which countries are able to make reductions. The per capita figures show, for example, that US emissions per head of population are more than twice those of Japan. If Japan is taken as a model energy-efficient economy, it seems that there may be scope for reducing greenhouse emissions in the US and to a lesser extent in the Soviet Union and the European Communities. Emissions targets based on per capita figures would also benefit developing countries such as China, with low per capita emissions. The high per capita figure for Brazil is explained by the high rate of deforestation in that country in $1987 . \quad$ Peter Aldhous

Paris VI (Jussieu) will house the IGBP data and information system directory. Co-funded by the US National Aeronautics and Space Administration (NASA) and the French government, the office will serve as a clearing house for Earth observation satellite data, ensuring compatibility and links with other databanks. The centre will be directed by S. Ichtiaque Rasool, scientific director at NASA in Washington, from 1 October.

One of the goals of IGBP is to be able to make long-term predictions of climate change. Woods thinks that this will be feasible in 20 years, but that a start needs to be made "in the next 2-3 years".

According to Woods, "if governments do not take this decision (to implement IGBP), they will have consciously decided not to base their policies on the best available predictions". Funding could be a problem, despite the political enthusiasm for global change research. This year, IGBP fell $\$ 500,000$ short of its $\$ 1.6$ million target budget for administration.

Peter Coles 